\title{
The Quality of Customer Service and the Level of Consumer Satisfaction in Timor Leste Telecommunications
}

\author{
Marna Sarmento Baptista ${ }^{1}$, Cristina Galamba Marreiros ${ }^{2}$, Maria Raquel Lucas ${ }^{3 *}$ \\ ${ }^{1}$ Timor Telecom, Timor Plaza, Rua Presidente Nicolau Lobato, 4ำ, Caixa Postal 135, Díli, TIMOR-LESTE \\ ${ }^{2}$ Assistant Professor, Management Department, Évora University, Largo dos Colegiais, 2, 7000-645, Évora, PORTUGAL \\ ${ }^{3}$ Associated Professor, Management Department, Évora University, Largo dos Colegiais, 2, 7000-645, Évora, PORTUGAL \\ "E-mail for correspondence: mrlucas@uevora.pt
}

https://doi.org/10.18034/abr.v9i3.273

\begin{abstract}
The quality of customer services and its resulting consumer satisfaction have greatly contributed to the success of numerous companies, since they constitute competitive advantages, helping companies retaining their costumers and contributing to the company's recruitment of new clients. Satisfied customers are likely to return and recommend the service to friends and family. The goal of this research was to evaluate perceived service quality and customer satisfaction with the company Timor Telecom. Data was collected through a questionnaire applied to a sample of customers in Dili. The results indicated that customers are globally satisfied with the company and that the most relevant service quality dimensions were: products and services, the company itself, collaborators, and pointof-sale.
\end{abstract}

\section{JEL Classification Code: M 31}

Key words: Quality, service, satisfaction, customer, telecommunications

\section{INTRODUCTION}

Consumer satisfaction is a marketing concept very important for companies' sustainability. Consequently, customer service becomes a key goal for many organizations, especially due to the increasing competitiveness and instability of the markets.

Companies' never-ending search for new methods to remain in the marketplace is expressed by their attempt to offer something that their competitors cannot, so they can get customer preference. The survival of an organization is determined by its capacity to innovate and discover original ways to satisfy the needs of current and potential clients, creating products and services that generate value (Kotler and Armstrong, 2013).

The essence of marketing is to satisfy every need and desire of organizations' clients in different markets (Kotler and Keller, 2006). Within this approach, relational marketing aims to develop and maintain a permanent exchange with consumers and, therefore, reject shorttermed relationships (Gronroos, 2004; Gummesson, 2004). Its purpose is to build strong and lasting alliances between the companies and their customers. The evolution of relational marketing is fundamentally connected to the development of the information society, as well as, to the acknowledgment of the limitations of the transactional approach in saturated and very competitive markets. The advantages, in the latter approach, no longer come from the attributes of the product but, instead, from clients' satisfaction (Egan, 2003).

Satisfaction has been defined in distinct manners, from being an evaluation of product performance, based on previous experiences (positive and negative) (Woodruff, 1997; Jones et al., 2000), to the degree of consumer fulfillment with the use of a particular product or service (Marques, 2012). Nevertheless, the definition that prevails is the one proposed by Oliver (1980), in which client satisfaction is seen as an attitude or an assessment formed through the comparison of previous expectations and with the product's / service's actual performance. As stated by Johnson et al. (1995), satisfaction is simultaneously the result of a specific transaction (being a specific evaluation of purchase) and the result of a cumulative experience. Therefore, two types of satisfaction can be identified: transactional satisfaction, solely associated with the transaction 
(Shankar et al., 2003) and relational satisfaction, related to the overall consumption process (Bouguerra and Mzoughi, 2011).

Quality and customer satisfaction are terms that cannot be separated (Oliver, 1997). This paradigm led to significant modifications in management models, bringing into the management scene notions of shared leadership, decentralization, reduction of bureaucracy, collaborators' involvement at all levels of the companies' processes, staff and customer satisfaction (Soares, 2002). Quality is understood as the difference between clients' expectations and their product or service perceptions (Grönroos, 1984; Parasuraman et al., 1988), and as an antecedent of consumer satisfaction (Oliver, 1993; Fornell et al., 1996; Hurley, 1998; Silva, 2009).

According to Carr and Littman (1992), investing in quality goes from supplying better services to expenses reduction and the recruitment and preservation of high-quality staff. Consequently, customer service quality is not only considered a competitive advantage but also a method for keeping good employees. Alves (2003) believes that to evaluate a company's work and its sustainability, one must analyze its customer satisfaction and the clients' assessment of the service provided. Therefore, the knowledge of the factors that influence those assessments is crucial to the organizations (Rukhsana et al., 2012). This information allows action planning based on client perspectives and expectations, in order to create innovative products and services that fulfill their needs.

\section{Study Objectives}

Considering the above rationale, the main objective of the present study was to analyze the service quality and client satisfaction in Timor-Leste Telecommunications. To achieve that goal, it was necessary to implement a wide literature review on the importance of quality in customer service, as well as to evaluate clients' opinion of Timor Telecom (TT) service quality and their consequent level of satisfaction, whilst identifying the factors that contribute to that satisfaction in the telecommunications sector.

\section{LITERATURE REVIEW}

\section{Quality in Customer Service}

To provide a service means to attend to the needs of clients thoughtfully, with courtesy and attention, to really listen to them carefully. The quality of customer service relates to the performance of an organization and the impression it creates on its clients; therefore, the leaders' job is to motivate their collaborators into providing services that consider the needs and expectations of their customers. Every member of a company or organization should, on a daily basis, strive to perform to the best of their abilities, so that they remain engaged with the project and improve prospects (Moller, 2002).

Nowadays, differentiated customer service is a vital goal for many companies. The quality of customer service is as associated with the way employees manage to fulfill clients' expectations, as much as with, the understanding and care presented by the service provider.

Collaborators must be conscious of their position and acknowledge its importance. Their efforts not only form the client's perceptions but also help shape the overall opinion on staff quality and their performance (Moller, 2002). Satisfaction and dissatisfaction are ultimately a result of the comparison between product performance and the presumptions the client had on it (Kotler, 2010).

When a company offers good customer service, the client recognizes its value and, generally, becomes satisfied, even if the company does not deliver the demanded service. This fact generates questions regarding clients' perceptions of value, a theme that has been studied by several authors (Anderson et al, 1994, Ravald and Grönroos, 1996, McDougall and Levesque, 2000, Silva, 2009, Silva et al., 2011) as being an antecedent of satisfaction. These studies have also been conducted in Telecommunications (Turel and Serenko, 2006). From a management point of view, the focus on the client and on relationships based upon trust and credibility are vital to maintain and attract customers. Moreover, complaints and suggestions management is fundamental to correct possible mistakes that could develop into harsh consequences (e.g. negative image and consequent loss of clients/lack of new ones). An efficient complaints management increases client satisfaction and improves the company's performance (Ovenden 1995; Levesque and McDougall, 1996; Nyer, 2000; Johnston, 2001).

Kotler (2010) claims that costumer service concerns every activity that allows the client to get in touch with the correct staff member in a company, so he can get the services, answers or solutions to his problem quickly and satisfyingly. To guarantee that this goal is attained, service providers must know which are the basic requisites of good customer service, since the success of any business depends on that customer service quality (Bogman, 2002).

The contact between an employee and a client influences the affiliation of the client with the company. Meaning that customer service correlates directly with the deals that the company might or might not accomplish, and therefore the company becomes somehow dependent on the individuals that contact directly with the clients (Carvalho, 1999).

The basic criteria for good customer service are identified in Table 1. 
Table 1: Basic Requisites of Satisfactory Customer Service

\begin{tabular}{|c|c|}
\hline Requisites & Explanation \\
\hline To Know & $\begin{array}{l}\text { The functions, the company, the norms, } \\
\text { and the procedures. } \\
\text { An employee must be aware of his role } \\
\text { within the company, the way the } \\
\text { company is structured, and the rules and } \\
\text { procedures needed for his work to be } \\
\text { successful }\end{array}$ \\
\hline To Listen & $\begin{array}{l}\text { Understand the client } \\
\text { It is not possible to deliver customer } \\
\text { service without knowing his needs and } \\
\text { wants. It is of the utmost importance to } \\
\text { listen to the client, to be able to } \\
\text { communicate not based upon guesses } \\
\text { and not lead to clients' frustration. }\end{array}$ \\
\hline To Speak & $\begin{array}{l}\text { Simple, clear and objective language. } \\
\text { After listening to the client carefully, } \\
\text { speaking is needed to communicate. The } \\
\text { employee must convey information in an } \\
\text { adequate language, avoiding terms that } \\
\text { are too technical or that are not up to the } \\
\text { standards (i.e. abbreviations or slang). } \\
\text { Language should be clear, objective and } \\
\text { in line with the client's level of } \\
\text { knowledge }\end{array}$ \\
\hline To & The client as a whole. \\
\hline Understand & $\begin{array}{l}\text { Clients' gestures, facial expressions, and } \\
\text { posture are messages, which might help } \\
\text { to understand him. As every person is } \\
\text { different, perception is a fundamental } \\
\text { factor to understand and predict } \\
\text { different reactions. As a result, every } \\
\text { service encounter can be personalized } \\
\text { and unique. }\end{array}$ \\
\hline
\end{tabular}

Source: Marques, 1997

According to Kotler (2010), good customer service presupposes the development of a relationship with the client, one in which the employee listens to the client's needs, solves the problem quickly and effectively and reveals knowledge of the products he is responsible for. One must avoid saying 'I don't know' at all costs and aim to exceed the client's expectation instead.

Marques (1997) states that several factors might influence customer service. Amongst them, stress, reluctance to change, professional valorization, training, experience, leadership, and quality of life at work (QLW). Schermerborn (2000), affirm that any attitude and behavior that reflect a lack of motivation to endorse or support the desired change - resistance to change generate a lack of flexibility in service provision and does not improve performance.

Professional valorization makes the employees more prone to change their customer service behavior, inducing better financial results and improved corporate image. Nevertheless, the leader's profile is also of crucial importance in this process, as he is required to motivate his employees, develop a friendly environment, facilitate integration and promote flexibility.

Moller (2002), argued that if all of those who intervene in an organization performed their duties correctly, the future of the company would not be questioned at all. Since that is the leader that has the capacity to incentive the employees to adopt an attitude of continuous improvement in their jobs, the profile of the leader is determinant of customer service quality.

Training of employees is another fundamental factor for customer service. Qualifications induce assurance and, consequently, influence the employee's aptitude to serve. The employee's quality of life at work (QLW) is also improved with training, which is, in turn, directly correlated to an increase in service quality (Vasconcelos, 2006). The same author defines QLW as the set of actions implemented by a company to adopt innovations and upgrades of management, processes, technology and work environment. QLW programs favor employees who are willing to contribute to the organization, improving customer service.

Stress also influences customer service, and it must be reduced to a minimum. Nowadays, it is recommended that upon an employee's arrival at a company, he becomes integrated as well as an active member entitled to prospects of self-fulfillment and realization. Factors such as job security, wages, bonus, and work environment have ceased to be the sole reason for an employee's satisfaction (Julião, 2009).

A better customer service quality results in greater satisfaction of the employee with the company and with the product or service he is providing (Kotler, 2010). This is particularly true in dynamic and competitive markets on which survival strategies must be based on technological innovation and client satisfaction management strategies (Miranda, 2007).

\section{Satisfaction and Service Quality}

According to Kotler (2010), satisfaction is a feeling of pleasure or disappointment that results from a comparison between expectation and performance of a product/service, and, ultimately, is grounded on matters of quality perceptions. Kotler (2010), considers that satisfaction implies being conscious of the need to perform well when serving a customer, even if the customer is making a complaint. A client, whose complaint is solved reasonably, may remain with the company, even with stronger links than that of a client who has never experienced any dissatisfaction or had a complaint.

Parker and Mathews (2001), sate that satisfaction is dependent on the clients' perception of a product's 
performance when compared to their prior expectations; therefore, satisfaction can be seen as either a process or a result. Table 2 summarizes the main definitions of satisfaction, as found in the literature.

Table 2: Client Satisfaction Definitions

\begin{tabular}{|c|c|}
\hline Requisites & Explanation \\
\hline $\begin{array}{l}\text { Howard and } \\
\text { Sheth (1969) }\end{array}$ & $\begin{array}{l}\text { Satisfaction is the client's cognitive state } \\
\text { resultant from the comparison between } \\
\text { the sacrifice and the reward linked to } \\
\text { the service or product purchase. }\end{array}$ \\
\hline Day (1977) & $\begin{array}{l}\text { Satisfaction is a reaction to one's } \\
\text { conscious evaluation of the conditions } \\
\text { before and after consumption. }\end{array}$ \\
\hline $\begin{array}{l}\text { Churchill and } \\
\text { Surprenant } \\
(1992)\end{array}$ & $\begin{array}{l}\text { Satisfaction is the result of a comparison } \\
\text { between the costs and the rewards of a } \\
\text { purchase and its anticipated } \\
\text { consequences. }\end{array}$ \\
\hline $\begin{array}{l}\text { Westbrook and } \\
\text { Reilly (1983) }\end{array}$ & $\begin{array}{l}\text { Satisfaction is a pleasant emotional } \\
\text { state, resulting from a product, shop, } \\
\text { service or customer's action leading the } \\
\text { company towards its goals. }\end{array}$ \\
\hline $\begin{array}{l}\text { Tse and Wilton } \\
(1988)\end{array}$ & $\begin{array}{l}\text { Satisfaction is the consumer's response } \\
\text { to the evaluation of the perceived } \\
\text { discrepancy between his previous } \\
\text { expectations (or standards) and the } \\
\text { actual perceived performance of a } \\
\text { product. }\end{array}$ \\
\hline Hunt (1977) & $\begin{array}{l}\text { Satisfaction is a result of the evaluation } \\
\text { of a purchasing experience at least as } \\
\text { good as expected. }\end{array}$ \\
\hline Oliver (1997) & $\begin{array}{l}\text { Satisfaction is an evaluation of the } \\
\text { characteristics of a product or service } \\
\text { which provides a pleasant level of } \\
\text { fulfillment related to its consumption. It } \\
\text { also includes levels of over or sub } \\
\text { evaluation. }\end{array}$ \\
\hline Kotler (1991) & $\begin{array}{l}\text { Client satisfaction is the difference } \\
\text { between clients' opinions of the product } \\
\text { performance and their expectations. It is } \\
\text { a function of cognition, performance, } \\
\text { and expectations. }\end{array}$ \\
\hline $\begin{array}{l}\text { Zeithaml and } \\
\text { Bitner (2003) }\end{array}$ & $\begin{array}{l}\text { Satisfaction is the response to customer } \\
\text { service. It is a client evaluation of the } \\
\text { product or service, as well as the feeling } \\
\text { of fulfillment that comes from the } \\
\text { purchasing experience and product } \\
\text { usage. }\end{array}$ \\
\hline
\end{tabular}

Source: Authors

In short, it can be said that if the product's performance does not correspond to the client's expectations, the client will be dissatisfied; if it matches the expectations, the client will be satisfied; if it exceeds the expectations, the client will not only be satisfied but incredibly pleased. Satisfaction can also be defined as the evaluative judgment after the act of purchasing (Oliver, 1999; Churchill and Suprenant, 1992; Oliver and De Sarbo, 1988). Turel and Serenko (2006), concluded that when it comes to mobile phones, satisfaction is fundamentally resultant from the difference between practical use and perceived value.

Detzel and Desatnick (1995) sustain that client satisfaction, produced by organizations, their departments, activities, and people is ultimately the degree of happiness experienced by a client as well as the core reason for customer loyalty. They add that customers tend to communicate their experiences, positive or otherwise, to potential clients, which is a relevant factor for a company's success. Kotler (2010) believes that satisfied clients purchase again and retell their pleasant experiences. Concerning, unsatisfied customers, the author argues that they are most likely to change to the services of a competitor, depreciating the products when they mention them.

Clients include external buyers of the company's services and products company, suppliers, local community, employees, collaborators, managers and supervisors (and shareholders if the company is a public one). Even though total client satisfaction is a hard task, the attempt to exceed the client's expectations can benefit a company, as it influences the demand and the purchasing frequency. Moreover, the probability to lose a client to the competition due to dissatisfaction decreases significantly (Hoffman et al., 2009).

According to Las Casas (2008), a satisfied client, loyal to a brand or company, is an intangible asset to an organization, since his actions influence, on average, five other clients, an excellent statistical feat. Hoffman et al. (2009) argue that to succeed, a company cannot undermine the importance of client satisfaction, or for that matter, lack a clear strategically orientation to achieve client satisfaction. Merely having a good product is not a competitive advantage when compared to focusing on making that product a landmark for quality and effective service (Hoffman et al., 2009).

Therefore, constantly evaluating clients' level of satisfaction and recognize its importance is essential for any organization. Nevertheless, as satisfaction is inherently connected to matters of pleasure and disappointment resultant from the comparison between product performance and expectations, the company cannot control all the variables which may lead to customer unloyalty (Zeithaml and Bitner, 2003).

Previous studies on client satisfaction rely fundamentally on two approaches (Johnston, 2001), the first considers it a specific transaction, whereas the second considers it to be a cumulative process. Vilares and Coelho (2005) state that the first approach is a post-purchase evaluative prognostic, and that the second approach concerns a 
global evaluation, merging of the purchasing experience and product consumption over time.

The approach to satisfaction as a cumulative process is the most rewarding, as it offers a greater performance indicator, based on the past, present and future. It encompasses a global evaluation of the client's experience with a particular service or product, up until the present, instead of offering the specific evaluation of a product or service at a precise moment. This approach holds another advantage, a greater capacity to predict economic performance, as the clients' decisions lie in the totality of their experiences, instead of a specific transaction or moment (Johnston, 2001).

According to psychological and social theory, clients' evaluations of satisfaction are justified by personal feelings of exchange equity, the disparity between desires and results, individual preference, social comparisons and other phenomena (more or less complex), leading to different attitudes on different consumers (Williams et al., 1998).

The topics of satisfaction and customer loyalty are central in many research papers and projects. However, none of these works has been implemented on East Timor, except for a United Nations' questionnaire on the telecommunications market (UNMIT, 2011). Amongst the studies on that subject, we emphasize the work of Turel and Serenko, 2006; Samuel, 2006; Miranda, 2007; Kang et al., 2009; Bayraktar et al., 2012; Uddin and Akhter, 2012; Mohafez et al., 2012; Asghar et al., 2012; Liu et al., 2013).

Mohafez et al. (2012) developed a study for Teheran's market, the capital of Iran, in which they found a significant positive connection between perceived expectations and perceived quality and value, being client satisfaction in a position of significance for customer attraction and maintenance. Samuel (2006) suggests to mobile telecommunication companies to maximize their client satisfaction (and therefore improve their businesses' performance), segment the market and adopt specific strategies for different customer segments. Bayraktar et al. (2012), through the development of a DEA approach (data envelopment analysis), concluded that in the growing market of Turkey it is more expensive to attract new clients than to keep the existent ones. Uddin and Akhter (2012) performed a study concerning the factors which influence client satisfaction in Bangladesh's mobile phones. It was found that perceived value holds a mediating role between quality, equity, and satisfaction.

\section{Research Methodology}

The present investigation adopted a descriptive approach for the analysis of client satisfaction in the telecommunications of East Timor. That analysis was done based on data collected through questionnaires to Timor Telecom S.A. clients, the leading operator in Timor Leste market. The main activities of the company are the mobile telephone system, landline, and internet. The questionnaire was applied, through personal interviews, to a convenience sample of 100 TT clients, residing in Dili.

The questionnaire used in the study was structured in two sections and followed the advice of Malhotra (2011) for questionnaire design. Namely, to have a short explanatory introduction, not to be too long, and structured so that there is a logical sequence in the presentation of the questions. Following the introduction, which presented the research and its purpose and guaranteed the confidentiality of the information provided, followed the two main sections. The first section aimed at the collection of demographic information, such as age, gender, nationality, level of education, occupation, and income. The second section included the scale to measure clients' satisfaction with various aspects of TT products and services. The 18 items included in the scale (see table 3 ) were valued by respondents on a 5 -point satisfaction scale from very satisfied to very dissatisfied. The items of the scale were adapted from Silva (2009) and Parasuraman et al (1988) to fit the TT context, products and services, and satisfaction measurement

The data gathered with that questionnaire was then analyzed with uni and multivariable descriptive statistical analysis in SPSS 16.0.

\section{ANALYSIS OF RESULtS}

Most of the questionnaire respondents are aged between twenty and fifty years old $(54 \%)$, male $(60 \%)$, work on the public sector $(53 \%)$, with a university degree $(59 \%)$, and an income superior to $\$ 1000$ a month $(60 \%)$.

Regarding their satisfaction with TT customer service, the majority of the sample was satisfied or very satisfied. The higher levels of satisfaction were related to the kindness of the employees $(51 \%)$, whereas the lower levels were related to employees' expertise (42\%). The level of satisfaction with the quality of the products and services of TT was also medium. These findings are similar to those obtained by Saha and Joshi (2019) and Sattar and Guohui (2019) and justify the importance of the company's focus on a better customer relationship management and their service quality. Also, Oduro et al. (2018) found a positive relationship between customer satisfaction and perceived product and service quality.

The levels of dissatisfaction are particularly high with malfunctions resolution $(45 \%)$, internet service $(20 \%)$ and information given by front-office staff $(11 \%)$. Satisfaction with TT general issues, particularly with the facilities is very high (65\%). Most of the respondents were little satisfied or dissatisfied with TT complaints management $(75 \%)$, with the interest showed by the company in solving the clients' problems $(78 \%)$, with the time the company takes to solve clients' problems $(72 \%)$ as well as with the call center service $(75 \%)$. 
After the above described descriptive statistical analysis of the sample, factor analysis was applied to the 18 satisfaction evaluation items. This analysis was done to achieve the research primary goal of analyzing satisfaction with TT customer service, whilst identifying the factors that contribute to that satisfaction in the telecommunications sector. As such factor analysis is the most adequate multivariate statistical analysis to uncover the underlying dimensions of phenomena, in this case of client satisfaction

The initial factor analysis included all the evaluation of satisfaction questionnaire items. A four factors solution was generated, based on the derivation of factors according to the eigenvalue criteria (above 1). In this model, the commonalities of all the items are above 0, 5 (Table 3), revealing that the originated factors explain a good proportion of the items' variance.

Table 3: Commonalities of the Satisfaction Scale Items

\begin{tabular}{|l|l|}
\hline Commonalities &, 749 \\
\hline Business Hours &, 751 \\
\hline Customer Service Area &, 758 \\
\hline Waiting Area &, 791 \\
\hline Employees' Kindness &, 745 \\
\hline Employees' Expertise &, 591 \\
\hline Response Time &, 610 \\
\hline Oral Information &, 589 \\
\hline Documents Issued &, 741 \\
\hline Mobile Service &, 724 \\
\hline Internet Service &, 702 \\
\hline Landline Service &, 648 \\
\hline Malfunctions Solution &, 709 \\
\hline Company Facilities &, 769 \\
\hline Associated Products &, 608 \\
\hline Call Center Service &, 756 \\
\hline Complaints Management &, 676 \\
\hline Interest in Solving Clients' Problems &, 716 \\
\hline Malfunctions Time of Response & \\
\hline
\end{tabular}

Source: SPSS output

Table 4 reveals that data correlation - as shown by the Bartlett test (sig $=.000$ ) and sustained by the value of the KMO (0.26) which, according to Silvério (2003), is considered "Good" - is indicative of the adequacy of the data to factor analysis.

Table 4: KMO Test and the Bartlett Scale of Satisfaction

\begin{tabular}{|l|l|r|}
\hline \multicolumn{3}{|c|}{ KMO and Bartlett's Test } \\
\hline KMO Measure of Sampling Adequacy. &, 726 \\
\hline \multirow{2}{*}{$\begin{array}{l}\text { Bartlett's Test } \\
\text { of Sphericity }\end{array}$} & Approx. Chi-Square & 866,924 \\
\cline { 2 - 3 } & Df & 153 \\
\cline { 2 - 3 } & Sig. &, 000 \\
\hline
\end{tabular}

Source: SPSS output

The number of factors to retain in the final factor solution was based on the eigenvalues and the explained variance. In order to explain the items' ambiguous saturations, the solution was rotated with the Varimax method, and the four factors final model is depicted in Table 5. In this model, the four factors explain, approximately, $70 \%$ of the variance of the eighteen initial variables, which is, according to Silvério (2003); a good value for social sciences.

Table 5: Model of the Factorial Satisfaction Analysis

\begin{tabular}{|l|c|c|c|c|}
\hline \multirow{2}{*}{ Items } & \multicolumn{4}{|c|}{ Component } \\
\cline { 2 - 5 } & $\mathbf{1}$ & $\mathbf{2}$ & $\mathbf{3}$ & $\mathbf{4}$ \\
\hline Business Hours &, 010 &, 187 &, 840 &, 092 \\
\hline $\begin{array}{l}\text { Customer Service } \\
\text { Area }\end{array}$ &,- 022 &,- 095 &, 813 &, 286 \\
\hline Waiting Area &, 241 &, 368 &, 746 &,- 090 \\
\hline $\begin{array}{l}\text { Employees' } \\
\text { Kindness }\end{array}$ &, 064 &, 866 &, 170 &, 088 \\
\hline $\begin{array}{l}\text { Employees' } \\
\text { Expertise }\end{array}$ &, 111 &, 852 &, 077 &,- 001 \\
\hline Response Time &, 558 &, 449 &, 280 &, 015 \\
\hline Oral Information &, 565 &, 522 &, 109 &, 082 \\
\hline Documents Issued &, 506 &, 476 &, 272 &, 180 \\
\hline Mobile Service &, 855 &,- 072 &, 061 &, 044 \\
\hline Internet Service &, 806 &, 181 &, 114 &, 172 \\
\hline Landline Service &, 723 &,- 248 &, 339 &, 063 \\
\hline $\begin{array}{l}\text { Malfunctions } \\
\text { Solution }\end{array}$ &, 536 &, 314 &,- 319 &,- 400 \\
\hline Company Facilities &, 395 &,- 095 &, 369 &, 638 \\
\hline $\begin{array}{l}\text { Associated } \\
\text { Products }\end{array}$ &, 086 &, 358 &,- 002 &, 796 \\
\hline Call Center Service &, 390 &, 377 &,- 330 &,- 453 \\
\hline $\begin{array}{l}\text { Complaints } \\
\text { Management }\end{array}$ &, 709 &, 464 &,- 179 &,- 075 \\
\hline $\begin{array}{l}\text { Interest in Solving } \\
\text { Clients' Problems }\end{array}$ &, 662 &, 463 &,- 122 &, 088 \\
\hline $\begin{array}{l}\text { Malfunctions Time } \\
\text { of Response }\end{array}$ &, 691 &, 471 &,- 086 &,- 101 \\
\hline Labels & Products & Employees & Store & Company \\
\hline Eigenvalues & 6,625 & 3,038 & 1,877 & 1,096 \\
\hline Cronbach's Alpha & 0,900 & 0,823 & 0,781 & 0,303 \\
\hline Variance (\%) & 36,8 & 16,9 & 10,4 & 6,1 \\
\hline $\begin{array}{l}\text { Cumulative } \\
\text { Variance (\%) }\end{array}$ & 36,8 & 53,7 & 64,1 & 70,2 \\
\hline Source: SPSS output &, 369 \\
\hline
\end{tabular}

Source: SPSS output

As expected, the factor solution extracted the factors by order of importance, being Factor 1 the highest value of explained variance $(37 \%)$, and Factor 4 the lowest value $(6 \%)$. The Cronbach alfa of the four factors was, respectively, $0,9,0,82,0,78$, and 0,3 . These values indicate that the internal reliability of the first three factors is good for research in social sciences. However, Factor 4 reveals a low Cronbach Alpha, reflecting low internal reliability. This value might be explained because this factor is the last subscale to be derived, which means, consequently, that it explains a relatively low percentage variance.

Nevertheless, it can be stated that this Factor Model has a good fit to the data and the variables analyzed. However, the internal reliability of Factor 4 could be improved to better qualify the factor in this model. Marreiros (2005) argues that, probably, the better form of improving 
reliability is through the addition of items to help to measure this dimension of satisfaction.

When analyzing Table 5, it is clear that Factor 1 is strongly

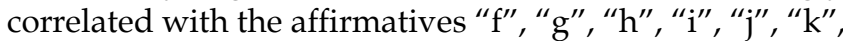
"l" e "p, "q"; " $r$ ". These items are related to consumer satisfaction with TT services and products, from the landline service to complaints management. Thus, this factor can be named as the 'Products' dimension. Therefore, it can be concluded that all the products and services offered by Timor Telecom are part of the same dimension, regardless of being paid for or not, or of being bought on-site or at a distance. It is important to underline that this factor is the most significant to explain the variation of the levels of client satisfaction.

Factor 2 is strongly associated with items " $\mathrm{d}$ " and " $\mathrm{e}$ " related to the employees' characteristics, which translate into their working skills, a determining factor for client satisfaction. Even though items " $\mathrm{g}$ ", " $\mathrm{h}$ " and " $\mathrm{f}$ " have a significant weight in factor 1, they are also significant for this dimension of the model, as they are related to the employee-customer dynamic (i.e the response time and the information offered are also considered when interpreting this factor). Consequently, factor 2 was named "Employees" and it refers to the importance of these features for the satisfaction of the clients at Timor Telecom.

The affirmatives " $a$ ", " $b$ " and " $c$ " are related to items that refer back to the facilities of Timor Telecom, and are grouped in Factor 3, labeled "Shop". The "Shop", where most clients interact with the company, is the third most important factor when explaining the respondents' satisfaction. Finally, the items " $\mathrm{m}$ " and " $\mathrm{n}$ " are related to the physical evidences of the company as a whole, and they are represented in Factor 4. Item "o" -Call Center Service - is also associated with this factor, even though a smaller weight and with a negative sign. This factor was called "Company" and it represents the aspects that are not so directly connected to on-site contact with the public or that are not seen by the respondents as associated with the company in general. This is the least important factor when explaining the variance in client satisfaction.

In short, the results of this analysis indicate that there are four important dimensions in the satisfaction and perceived quality of Timor Telecom clients. The respondents grouped their evaluations of satisfaction in the several dimensions which make up the whole Timor Telecom offer, from its products and services to the company, including its employees and shops.

Contrary to the present results Saha and Joshi (2019) grouped satisfaction and quality attributes in 5 factors. Nevertheless, their results also showed that enhancement of the customer experience as well as improving service quality, helps the implementation of suitable sustainable strategies for the mobile market today. These conclusions may help telecom players to enhance and retain their customer base and profit.

\section{Conclusion}

Consumer Satisfaction represents one of the most important concepts in relational marketing and it has been unanimously considered to be fundamental for a longlasting, mutually beneficial, and satisfactory relation between client and organization.

However, while the satisfaction with physical goods and services has been widely explored in academic research, investigation on this topic applied to telecommunications is scarce. Moreover, none of that research was conducted Timor Leste, except for this and a UNMIT study, both of an academic nature. This study is a small contribution to improve the knowledge in this area, aiming to understand the perspective of the clients on quality and customer service.

Service quality is fundamental to clients but also to the company, especially if the latter wants to keep or improve its place in a highly competitive market, as it is the telecommunications sector. This is the environment where TT is inserted and, even though the company is well implemented in the market, it needs to maintain its customers and eventually grow, especially under the new regime of market liberalization implemented in Timor. The literature review about customer satisfaction was essential to improve the knowledge of the themes involved.

Clients' opinions of TT customer service quality are, globally, positive, meaning that the customers are pleased and the service meets their needs. Nevertheless, it is important to recognize the impossibility of reaching maximum satisfaction, as everyone is different and requires a specific type of service or even particular privileges. Overall, the sense of satisfaction with all TT as a whole is higher than the level of satisfaction associated with TT's products. The satisfaction levels are even bigger with the facilities and the associated (promotional) materials as well as with the office hours, shops, environment, and employees. The higher levels of satisfaction are with employees' kindness and their competence. The levels of dissatisfaction are especially high in the Call Centre and Complaints services, particularly associated with the interest demonstrated and the time needed to solve the problems. The clients who are highly satisfied with the landline and the mobile service are solely a small percentage of the people inquired. Of all the items examined, complaints management had the worst level of quality, according to the respondents.

There are four dimensions associated with client satisfaction, which by order of importance are, products, employees, shop, and company. The products are the factor that contributes more to explain the variance in the level of client satisfaction. This result allows concluding that all the products and services provided by TT are part of the same dimension, regardless of being paid, free, and bought in a shop or at a distance. The factor which directly 
relates to the employees' characteristics, including their competence, social skills and time to process the information the importance of collaborators to customer satisfaction with TT. The facilities, where most of the experiences and transactions are held, are also important to explain respondents' satisfaction. The physical evidences of the company are the least important factor, perhaps because they are not directly related to customer service.

\section{ACKNOWLEDGMENTS}

The authors acknowledge the financial support of the Foundation for Science and Technology (UID/ECO/ 04007/2019).

\section{REFERENCES}

Alves, H. (2003). “Uma abordagem de marketing à satisfação do aluno no ensino universitário público: índice, antecedentes e consequências", Tese de Doutoramento em Gestão, Covilhã: Universidade da Beira Interior.

Anderson, E.W., Fornell, C. \& Lehmann, D.R. (1994). “'Customer satisfaction, market share, and profitability: findings from Sweden", Journal of Marketing, Vol. 58, July, pp. 53-66.

Asghar, A. J., Alireza, M. \& Amin, A, i (2012). “Mobile Commerce beyond Electronic Commerce: Issue and Challenges", Asian Journal of Business and Management Sciences, vol. 1 no. 2, pp. 119-129.

Bayraktar, E., Tatoglu, E.,Turkyilmaz, A., Delen, D. \& Zaim, S. (2012). "Measuring the efficiency of customer satisfaction and loyalty for mobile phone brands with DEA", Expert Systems with Applications, vol. 39, no. 1, Jan, pp. 99-106.

Bogman, I. (2002). Marketing de Relacionamento: estratégias de fidelização e sua implicações financeiras. São Paulo: Nobel.

Bouguerra, A. \& Mzoughi, M. N. (2011). "Relationship Marketing: The Forgotten Consumer". International Journal of Business and Social Science, vol. 2, no. 6, pp210-223.

Carr, D. K. \& Littman, I. D. (1992). "Excelência nos serviços públicos: gestão da qualidade total na década de $90 "$ ". Quality Marketing, Rio de Janeiro.

Carvalho, P. C. (1999). Administração Mercadológica. 1ed. Campinas: Alínea.

Churchill, G.A. \& Surprenant, C. (1992). “An investigation into the determinants of customer satisfaction", Journal of marketing research, vol. 19, nov, pp. 491- 504.

Day, R.L. (1977). "Extending the Concept of Consumer Satisfaction," in Advances in Consumer Research, 4, ed. William. Perreault, Jr., Cincinnati: Association for Consumer Research, 149-54.

Detzel, D. H. \& Desatnick, R. L. (1995). Gerenciar bem é manter o cliente. Pioneira, São Paulo.

Egan, J. (2003). "Back to the future: divergence in relationship marketing research", Marketing Theory, vol. 3, no. 1, pp. 145-57.

Fornell, C., Johnson, M. D., Anderson, E. W., Cha, J. \& Bryant, B. E. (1996). "The American Customer Satisfaction Index: Nature, purpose, and findings". Journal of Marketing, vol. 60, no. 4 , pp. 7-18.
Grönroos, C. (1984). "A service quality model and its marketing implications". European Journal of Marketing, vol. 18 no. 4, pp. 36-44.

Gronroos, C. (2004). "The Relationship Marketing Process: Communication, Interaction, Dialogue, Value", Journal of Business and Industrial Marketing, 19, 2, 99-113.

Gummesson, E. (2004). "Return on Relationships (ROR): The Value of Relationship Marketing and CRM in Business-toBusiness Contexts", Journal of Business and Industrial Marketing, vol.19 no. 2, pp. 136-48.

Hoffman, K.D., Bateson, J.E.G., Ikeda, A.A. \& Campomar, M.C. (2009). Princípios de Marketing de Serviços - Conceitos, Estratégias e Casos. Tradução da 3a Edição Norte-Americana. CENGAGE Learning.

Howard, J. A., \& Sheth, J. N. (1969). The theory of buyer behavior. New York: Wiley.

Hunt, K.H. (1977). "Customers Satisfaction /DissatisfactionOverview and Future Directions", in Hunt, K. H. Conceptualization and Measurement of Customer Satisfaction and Dissatisfaction, Marketing Science Institute, Cambridge, MA, pp.71-109.

Hurley, F., (1998), "Customer Service Behaviour in Retail Settings: A Study of the Effect of Service Provider Personality", Journal of the Academy of Marketing Science, vol. 26 no. 2, pp. 115-127.

Johnson, R., Tsiros, M. \& Lancioni, R. (1995). “Measuring service quality: a systems approach", Journal of Services Marketing, vol.9, no.5, pp. 6-19.

Johnston, R. (2001). "Linking complaint management to profit", International Journal of Service Industry Management, vol. 12, no. 1 , pp. $60-69$.

Johnston, R. (2001). "Linking complaint management to profit", International Journal of Service Industry Management, vol. 12, no. 1, pp. $60-69$.

Jones, M.A., Mothersbaugh, D.L. \& Beatty, S.E. (2000). "Switching barriers and repurchase intentions in services". Journal of Retailing, vol. 76, no. 2, pp. 259-74.

Julião, T. F. (2009). "Qualidade de Vida no Trabalho: Um estudo de caso realizado no Colégio Sete de Setembro". Monografia. Curso de Administração. Faculdade Sete de Setembro - FASETE. Paulo

Kang, J., Zhang, X. \& Zheng, Z. H. (2009). “The relationship of customer complaints, satisfaction and loyalty: Evidence from China's mobile phone industry", China-USA Business Review, Vol. 8, no.12 (Serial no.78), Dec., USA.

Kotler, P. \& Armstrong, G. (2013). Principles of Marketing. 15th ed., Prentice Hall.

Kotler, P. \& Keller, K. L., (2006). Administração de Marketing. $12^{\text {nd }}$ ed. Pearson/Prentice Hall.

Kotler, P. (1991). Administração e Marketing: análise, planejamento, implementação e controle. $2^{a}$ ed. São Paulo: Atlas.

Kotler, P. (2003). Administração de Marketing. São Paulo: Prentice Hall.

Kotler, P. (2010). Marketing para o Século XXI. Tradução de Saul Barata - 6aed. Lisboa, Editorial Presença.

Las Casas, A. L. (2008). Administração de vendas. 8a Ed., S Paulo.

Levesque, T. \& McDougall, G. H. G. (1996). "Determinants of customer satisfaction in retail banking". International Journal 
of Bank Marketing, vol. 14 no. 7, pp.12-20.

Li, H., Ye, Q. \& Law R. (2012). "Determinants of Customer Satisfaction in the Hotel Industry: An Application of Online Review Analysis". Asia Pacific Journal of Tourism Research, 18, pp. 1-19.

Liu, W. L., Jang, H. Y. \& Jang, Y. (2013). "Factors Affecting Consumer Perceived Advertising Value and Attitude toward Mobile Advertising: Focus on Company-factors and Consumer-factors", Asian Journal of Business and Management Sciences, vol. 3, no.2, pp. 44-55.

Malhotra, N. K. (2011). Pesquisa de marketing: uma orientação aplicada. Porto Alegre, Bookman.

Marques, A. (2012). Marketing Relacional - como transformar a fidelização de clientes numa vantagem competitiva. Lisboa: Ed. Sílabo.

Marques, F. (1997). Guia prático da qualidade total em serviços. São Paulo: APMS, 1ed.

Marreiros, C. (2005). “Consumers' Perceptions of and Attitudes to Beef: A Study of Labelled Beef in Portugal". Thesis of Doctor in Philosophy, University of Newcastle.

McDougall, G. H. G. \& Levesque, T. (2000). "Customer satisfaction with services: putting perceived value into the equation", Journal of Services Marketing, vol., 14 no. 5, pp. 392-410.

Miranda, C. M. (2007). “Qualidade do Serviço e Satisfação do Cliente. Caso Vodafone". Dissertação de Mestrado em Marketing, Universidade Católica Portuguesa, Centro Regional do Porto, Faculdade de Economia e Gestão.

Mohafez, H., Mirabi, V. \& Kheyri, B. (2012). "Effective factors on mobile phone customer satisfaction ". Management Science Letters, vol. 2, no. 3, pp. 1011-1016.

Moller, C. (2002). O lado humano da qualidade: maximizando a qualidade de produtos e serviços através do desenvolvimento das pessoas. São Paulo: Pioneira Thomson Learning.

Nyer, P. U. (2000). "An investigation into whether complaining can cause increased consumer satisfaction", Journal of Consumer Marketing, vol. 17 no.1, pp. 9-19

Oduro, E., Boachie-Mensah, F. O. \& Agyapong, Gloria K. Q. (2018). "Determinants of Customer Satisfaction in the Telecommunication Industry in Ghana: A Study of MTN Ghana Limited", International Journal of Marketing Studies, vol. 10, no. 3, pp. 101-115.

Oliver, R. L. \& De Sarbo, W.S. (1988), Response determinants in satisfaction judgments, Journal of Consumer Research, vol. 14, no. 4, pp. 495-507.

Oliver, R. L. (1980). "A cognitive model of the antecedents and consequences of satisfaction decisions". Journal of Marketing Research, vol. 17, no. 4, pp. 460-469.

Oliver, R. L. (1993). "Cognitive, affective and attribute bases of the satisfaction response", Journal of Consumer Research, vol. 20, no.3, pp. 418-430.

Oliver, R. L. (1997). Satisfaction: A behavioral perspective on the consumer. Singapore: McGraw Hill.

Oliver, R. L. (1999). Whence consumer loyalty?, Journal of Marketing, vol. 63 (Special Issue), pp. 33-44

Ovenden, A., (1995). "Keep your customers happy and your competition will slowly fade away", The TCM Magazine, vol. 7, no. 1, pp.46-49.
Parasuraman, A., Zeithaml, V.A. \& Berry, L.L. (1988) "SERVQUAL: a multiple-item scale for measuring consumer perceptions of service quality", Journal of Retailing, vol. 64, no. 1, Spring, pp. 12-40.

Parker, C. \& Mathews, B. (2001). "Customer Satisfaction: Contrasting Academic and Consumers Interpretations". Marketing Intelligence \& Planning, vol. 19, no. 1, pp. 38-44.

Ravald, A. \& Grönroos, C. (1996). "The value concept and relationship marketing", European Journal of Marketing, vol. 30, no. 2, pp. 19-30.

Rukhsana, G., Rehman, G.l. \& Niaz, A. B. (2012). “Determinants of Customer Satisfaction and Retention in Commercial Banks of Pakistan", Asian Journal of Business and Management Sciences, vol. 2, no. 1, pp. 107-112.

Saha, S. \& Joshi, Y. C. (2019). "Measuring Mobile Service Satisfaction: Factor Analysis Based Study on Mobile Users of Gujarat", International Journal of Basic Sciences and Applied Computing), Vol., no. 8, July, pp-10-16.

Samuel, E. (2006). "Customer Satisfaction in the Mobile telecommunications industry Nigeria", Master of Business Administration (MBA). Blekinge Institute of Technology, Department of Management, Ronneby, Suécia.

Sattar, A. \& Guohui, W. (2019). "Determinants of Customer Satisfaction in Pakistan Telecommunication", Asian Journal of Economics, Finance and Management, vol. 1, no. 2, pp. 7983.

Schermerborn, J. R. (2000). Fundamentos do comportamento organizacional. 2 ed. São Paulo: Atlas.

Shankar, V., Smith, A. K. \& Rangaswamy, A. (2003). "Customer satisfaction and loyalty in online and offline environments". International Journal of Research in Marketing, vol. 20, pp. 153175.

Silva, S. (2009). "Satisfação e Qualidade como Factor de Vantagem Competitiva dos Serviços de Call Center: Criação e validação de um instrumento de medição da satisfação dos consumidores", Dissertação de Mestrado em Gestão, especialização em Marketing, Universidade de Évora, Portugal.

Silva, S., Marreiros, C. \& Sousa, A. (2011). “Determinantes da satisfação dos consumidores nos serviços de cal center: um estudo empírico com consumidores brasileiros". Revista PMKT, pp. 12-23.

Silvério, M. C. C. (2003). "Pesquisa de Marketing". Publicações Universidade de Évora, Ciências Económicas e Empresariais, no 11.

Soares, V. (2002). A cultura organizacional e seus componentes. Charles Cultura (eds), Brasil.

Tse, D.K. \& Wilton, P.C. (1988). "Models of Consumer Satisfaction Formation: An Extension," Journal of Marketing Research, vol. 25, pp.204-212.

Turel, O. \& Serenko, A. (2006)." Satisfaction with mobile services in Canada: An empirical investigation", Telecommunications Policy, vol.30, pp. 314-331.

Uddin, M. B. \& Akhter, B. (2012). "Customer Satisfaction in Mobile Phone Services in Bangladesh: a survey research", Management and Marketing Journal, vol. X, no. 1, pp. 20-36.

UNMIT - United Nations Integrated Mission in Timor-Leste (2011). "Timor-Leste Communication and Media Survey", Dili, June 
Vasconcelos, A. F. (2008). "Qualidade de Vida no trabalho: Origens, Evolução e Perspectiva", Caderno de Pesquisas em Administração, São Paulo, v.8, no.1, jan/mar, pp.23-35.

Vilares, M. J. \& Coelho, P. S. (2005). A Satisfação e Lealdade do Cliente: Metodologias de Avaliação, Gestão e Análise. Lisboa, Escolar Editora.

Westbrook, R. \& Reilly, M.D. (1983). "Value- percept disparity: an alternative to the disconfirmation of expectations theory of consumer satisfaction", in Bagozzi, R.P. and Tybout, A.M. (Eds), Advances in Consumer Research, Association for Consumer Research, Ann Arbor, MI, pp. 256- 61.
Williams, B., Coyle, J. \& Healty, D. (1998)."The meaning of patient satisfaction: an explanation of high reported levels", Social Science and Medicine, vol. 47, no. 9, pp. 1351-1359.

Woodruff, R. B. (1997). "Customer value: The next source for competitive advantage", Journal of the Academy of Marketing Science, vol. 25, no. 2, pp 139-153.

Zeithaml, V.A. \& Bitner, M.J. (2003). Marketing de serviços: a empresa com foco no cliente, 2.ed. Porto Alegre: Bookman.

$--0-$

Online Archive: https://abc.us.org/ojs/index.php/abr/issue/archive 